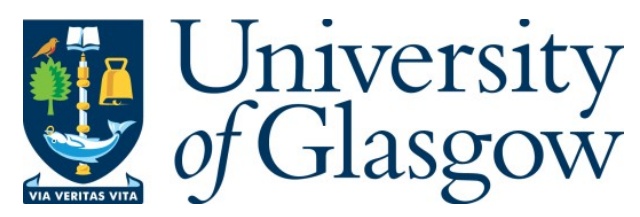

Danbolt, J., Siganos, A., and Vagenas-Nanos, E. (2015) Investor sentiment and bidder announcement abnormal returns. Journal of Corporate Finance, 33, pp. 164179.

There may be differences between this version and the published version. You are advised to consult the publisher's version if you wish to cite from it.

http://eprints.gla.ac.uk/107511/

Deposited on: 17 July 2015

Enlighten - Research publications by members of the University of Glasgow http://eprints.gla.ac.uk 


\title{
Investor Sentiment and Bidder Announcement Abnormal Returns
}

\author{
Jo Danbolt \\ University of Edinburgh, 29 Buccleuch Place, Edinburgh, EH8 9JS, UK \\ Email: Jo.Danbolt@ed.ac.uk
}

\author{
Antonios Siganos \\ University of Glasgow, University Avenue, Glasgow, G12 8QQ, UK \\ Email: antonios.siganos@glasgow.ac.uk
}

\author{
Evangelos Vagenas-Nanos* \\ University of Glasgow, University Avenue, Glasgow, G12 8QQ, UK \\ Email: evangelos.vagenas-nanos@glasgow.ac.uk
}

*Corresponding Author: Adam Smith Business School, Accounting and Finance Division, University of Glasgow, West Quadrangle, Main Building, University Avenue, Glasgow G12 8QQ, Scotland, E-mail: Evangelos.Vagenas-Nanos@glasgow.ac.uk, Tel: +44 (0)141 330 7677, Fax: +44 (0)1413304442

Acknowledgements: We are grateful to an anonymous referee, Jeffry Netter (the editor), Ilanit Gavious, Marc Goergen, Alan Goodacre, Dimitris Petmezas, Bill Rees, Lucia Spotorno, Yannis Tsalavoutas, Patrick Verwijmeren, Betty Wu, participants at the BAFA (London) 2014, EFMA (Rome) 2014, and WFC (Venice) 2014 conferences, and seminar participants at the Universities of Edinburgh, Glasgow, and Stirling for helpful comments on previous versions of this paper. Jo Danbolt holds the Baillie Gifford Chair in Financial Markets, and his research is partially funded by a Baillie Gifford endowment held by the University of Edinburgh Business School. Baillie Gifford has no role in or influence over the research conducted. 


\title{
Investor Sentiment and Bidder Announcement Abnormal Returns
}

\begin{abstract}
We introduce the significance of a direct sentiment proxy as an explanatory variable of bidder announcement returns. We argue that sentiment subconsciously influences investor perception of potential merger synergies and risks, and therefore relates to bidder abnormal returns. We proxy daily sentiment based on Facebook status updates across seventeen international markets and show that there is a positive relation between sentiment and bidder announcement returns. In line with behavioral literature stating that sentiment more heavily influences uninformed traders, this relation is more pronounced in acquisitions with a low percentage of blockholder ownership, acquisitions of US public targets, and acquisitions of large targets relative to the size of the bidders. Our study goes beyond the conventional sentiment and stock market returns literature, uncovering a significant relation between sentiment and firm-specific abnormal returns to acquiring companies.
\end{abstract}

Keywords: Mergers, bidder announcement returns, behavioral finance, investor sentiment. JEL classification: G1, G34 


\section{Introduction}

There is extensive literature (e.g., Eckbo, 2009) discussing the relation of acquirer- and dealspecific characteristics with acquirers' announcement returns. If investors are rational, in line with the expectations of the efficient markets hypothesis (Fama, 1970), the share price reaction of the acquiring firm on the announcement date of an acquisition should reflect the expected net present value of the acquisition (i.e., the discounted target firm value plus the value of potential synergies minus the amount paid to the target company's shareholders). This paper relaxes the assumption of strict investor rationality and argues that a behavioral aspect is related with bidders' short-term wealth effects. Investor sentiment is expected to influence investor perception of potential synergies and risks involved in the acquisition, leading to an irrational component of the share price reaction. Such misvaluations are expected to be of a short-term nature and to be arbitraged away over the days following the bid announcement (Officer, 2007).

A number of psychological studies have shown that sentiment has an impact on judgment. Mitchell and Phillips (2007) report that even small changes in sentiment may have an impact on neural activation and cognition, such as on participants' ability to plan, memorize, and think creatively. Investors who are in a good mood tend to make more optimistic decisions (Wright and Bower, 1992; Bless et al., 1996). A number of studies in the field of finance have indeed empirically validated the positive relation of sentiment with stock market returns. For example, Edmans et al. (2007) find that sports results are related with contemporaneous stock market indexes, in that a country's win/loss in sports is related with a positive/negative corresponding stock market reaction. Palomino et al. (2009) report that share prices of winning British soccer clubs overreact to information. Hirshleifer and Shumway (2003) show that abnormal weather conditions are positively related with 
contemporaneous stock market returns. Kaplanski and Levy (2010) report that aviation disasters negatively influence people's sentiment, and negative stock market returns are experienced shortly after, even for companies not affected by the event. The positive relation between sentiment and stock returns has also been supported by a number of studies (e.g., Lemmon and Portniaguina, 2006) that use direct monthly sentiment proxies through surveys, such as the University of Michigan Consumer Sentiment Index. According to Johnson and Tversky (1983) and Loewenstein et al. (2001), sentiment influences not only the judgment of favorable future prospects, but also the assessment of risk. Kaplanski et al. (2014) survey investors and find that happy investors not only are positive on expected stock returns, but also believe that the risks involved are relatively low.

We hypothesize that for mergers announced on days with optimistic market sentiment, investors are subconsciously more likely to overestimate potential synergies and underestimate the risks associated with the merger. On counterpart merger announcement days with low investor sentiment, investors would subconsciously be pessimistic regarding expected synergy benefits and perceive the potential risks of the acquisition to be high. We therefore hypothesize that sentiment is positively related to bidder announcement returns. We believe this study is the first to explore the relation of a direct sentiment proxy with bidder announcement abnormal returns. Note that while prior studies find the overall stock market index to be positively correlated with market sentiment, we explore the relation between market sentiment and the market's reaction to firm-specific bid announcements. This study thus goes beyond the conventional relation between sentiment and stock returns, and we explore bidder abnormal stock returns, in excess of the corresponding stock market returns. Uncovering a significant relation between sentiment and the stock market reaction to acquisition announcements, this study provides new insights into the relation between 
sentiment and share returns. Our findings suggest behavioral aspects are related to investors' perceptions of risk and synergies of mergers and acquisitions.

It may be argued that the shares of merging firms are heavily traded by professional investors, and therefore that any irrational component to the share price reaction upon bid announcement is unlikely. However, there is evidence to suggest professional investors may also be liable to be influenced by sentiment, with e.g., Kaplanski and Levy (2013) reporting that US analyst recommendations are influenced by sentiment, and Kling and Gao (2008) showing that stock returns and contemporaneous Chinese institutional investor sentiment are positively related. ${ }^{1}$ Professional investors are, though, influenced by sentiment to a lesser extent than uninformed traders (e.g., Lemmon and Portniaguina, 2006). We therefore expect any relation between sentiment and bidder abnormal returns to be short-lived, and for there to be signs of a reversal of any effect of sentiment on share returns over the days following the bid announcement, as any pricing anomaly is exploited by merger arbitrageurs.

In the main analysis, we use the Gross National Happiness Index (GNH) from Facebook to capture sentiment on the days around merger announcements. The GNH index offers significant advantages over conventional sentiment indexes. ${ }^{2,3}$ First, Facebook data is available with a daily frequency, which enables us to explore sentiment during merger announcements, while conventional sentiment indexes are available on a monthly basis. ${ }^{4}$ Second, the GNH index is available for seventeen international markets, including the US market, giving an international dimension to the validity of our results. Third, while

\footnotetext{
${ }^{1}$ There is evidence even beyond the finance field that professionals are influenced by non-rational factors. For example, Glejser and Heyndels (2001) report that expert judges in the Queen Elisabeth International Music Competition tend to award higher marks to musicians that perform later in the competition.

${ }^{2}$ See Siganos et al. (2014) for further details on the merit of GNH as a market sentiment index.

${ }^{3}$ Other commonly used sentiment indexes include the University of Michigan Consumer Sentiment Index and the Consumer Confidence Index.

${ }^{4}$ Note that the Gallup Economic Confidence Index offers daily US sentiment data. However, Gallup's coverage is shorter in length than that of the GNH, and its coverage is limited to the US market. For robustness, we explore US results with Gallup later in the study.
} 
traditional sentiment surveys tend to be based on relatively small samples of hundreds or, at most, a few thousand respondents, the Facebook GNH index is based on several million daily status updates. By 2014, there were almost 1.3 billion active Facebook users worldwide (Kuchler, 2014). The index can thus be argued to capture the overall sentiment of a large proportion of a country’s population.

We acknowledge that there may be certain limitations of the Facebook GNH index for our research purposes. Facebook users may have been young when Facebook was first introduced in 2004, and few are likely to have been investors. However, in later years there has been a significant increase in the age profile of users. Kramer and Chung (2011) use a sample period between September 2007 and February 2010 and find that over a quarter of Facebook users are older than 45, and less than ten percent are teenagers. Recent research (Kramer et al., 2014, p. 8788), also using Facebook data, finds “...emotional states can be transferred to others via emotional contagion, leading people to experience the same emotions without their awareness". Thus, even if a relatively small proportion of Facebook users are investors, it is possible that investors' sentiment is influenced by that of people around them, which arguably may be captured by Facebook, given its very widespread use. Indeed, Karabulut (2013) and Siganos et al. (2014) validate the relevance of the Facebook sentiment index to capital markets by showing that it is positively related with contemporaneous stock market returns. Their findings are consistent with evidence from conventional monthly sentiment proxies. There is, thus, prior evidence of sentiment, as proxied by Facebook’s GNH index, influencing share prices.

Our study is the first to use Facebook's sentiment data within the mergers and acquisitions field, looking at the relation between sentiment and bidder abnormal returns. However, as a robustness test, we also use the Gallup Economic Confidence Index as a proxy 
of market sentiment. While also available on a daily basis, the Gallup Index is, however, only available for the US and for a slightly shorter time period than the GNH Index. Analysis of the US sub-sample using the Gallup Index produces similar results to those obtained using Facebook's GNH, suggesting our results are not driven by the choice of sentiment proxy. However, given the larger sample of countries and the longer period of data availability, we base our main analysis on the Facebook GNH index data.

We use GNH data between September 2007 and March 2012 and empirically support that GNH is related with bidder announcement returns. ${ }^{5}$ The average cumulative abnormal returns within a four-day period from the merger announcement day to three days after $(0,+3)$ are 2.06 (0.92) percent in the highest (lowest) GNH quartile. The difference in returns between the high and low GNH portfolios is economically large and statistically significant at the one percent level. Results hold when controlling for a number of variables that have previously been found to be related with bidder returns. We estimate bidder abnormal stock returns, and therefore our results indicate a relation that goes beyond the typical sentiment and stock market returns (e.g., Lemmon and Portniaguina, 2006). In a further robustness test, we find that the relation between sentiment and bidder stock returns is more pronounced during the merger announcement period than during a random period prior to the merger announcement (such as over the period from day -12 to -10 relative to the day of the bid announcement), offering further credence to the suggestion that market sentiment seems to influence the stock market reaction to merger announcements.

In line with our hypothesis, sentiment seems to influence investor perception of potential synergies and/or the risk involved in the deal. On days with positive sentiment,

\footnotetext{
${ }^{5}$ In untabulated results, we empirically find that there is no relation between sentiment and target announcement returns. Targets experience little, if any, uncertainty relating to their announcement returns, since the majority experience significant gains (e.g., King, 2009) and the uncertainty regarding the value of the investment falls largely on the bidder.
} 
investors would appear to be more likely to overestimate potential synergies and underestimate the risks associated with the merger, with the reverse being likely on days with negative sentiment. We further find evidence of the positive relation between GNH and bidder announcement abnormal returns to at least partially reverse over the days following the merger announcements, giving further support to the argument that the reaction to the announcement was likely an irrational short-term overreaction to information.

We further explore sub-samples for which sentiment is expected to have a more or less pronounced effect on bidder returns based on prior literature finding that sentiment more heavily influences less informed investors (e.g., Lemmon and Portniaguina, 2006). Potential validation would offer further credence to the argument that sentiment is the driver behind the key relation reported in the study. We explore the relation between bidder returns and GNH in acquisitions by bidders with different levels of blockholder ownership, in acquisitions of public versus private target firms, and in acquisitions with different levels of relative target size. In particular, we hypothesize that the relation between GNH and bidder returns is more pronounced within firms with low levels of blockholder ownership, since small investors have been found to be more heavily influenced by sentiment (e.g., DeLong et al., 1990). We also hypothesize that the relation is more pronounced within acquisitions of public rather than private target firms. Public acquisitions are typically larger transactions and tend to attract more media attention (e.g., Fang and Peress, 2009), and small investors are heavily influenced by media coverage when selecting firms in which to invest (Barber and Odean, 2008). Finally, we hypothesize that the relation is stronger if the size of the target is large relative to the size of the bidder. Not only are acquisitions of large targets likely to attract more media attention, but any behavioral biases in valuing targets can be expected to have a larger impact on bidder returns where the target is relatively large. We empirically support the above hypotheses. 
This study contributes to the literature in several ways. We first contribute to the behavioral finance literature. While behavioral finance studies (e.g., Edmans et al., 2007; Hirshleifer and Shumway, 2003; Siganos et al., 2014) tend to show that sentiment is positively related with aggregate stock market performance, we study the relation between sentiment and individual firms' returns, finding sentiment to have a significant relation with bidder abnormal returns during their merger announcements. Our results highlight a relation beyond the typical sentiment and stock market returns relation reported in previous studies, indicating the influence of sentiment on investors' perception of synergies and risks associated with mergers and acquisitions. We also develop predictions, based on behavioral literature, as to which takeover transactions are likely to be more affected by sentiment than others, and empirically test these predictions. Focusing on the merger context, we show for the first time that sentiment has a stronger relation with bidder returns for bidders with a low percentage of blockholder ownership, in acquisitions of large targets relative to the size of the bidders, and, for the US sub-sample, in acquisitions of public targets. We further contribute to the merger literature by empirically validating for the first time the relation of a direct investor sentiment proxy on bidder announcement abnormal returns.

Our study is most closely related with Rosen (2006), who reports that US bidder announcement returns are more likely to increase in 'hot' merger markets, as defined by recent mergers with good announcement performance and periods with good overall stock market performance. Both Rosen's study and ours find that behavioral aspects are related with bidder announcement returns. Rosen's (2006) explanation is that there is momentum in investor perception of potential synergies from mergers, implying that the level of optimism in a market is related with bidder announcement performance. He finds a short-run overreaction for deals announced during hot merger periods, and a long-run price correction, and attributes this to investor sentiment. Our study instead uses a direct daily proxy of 
sentiment across international markets to highlight the importance of sentiment during merger announcements on contemporaneous bidder announcement abnormal returns. The study is also related to extensions of the neoclassical theory, according to which behavioral aspects impact firm managers' decisions on the timing of mergers and the selected method of payment (e.g., Shleifer and Vishny, 2003; Rhodes-Kropf and Viswanathan, 2004; RhodesKropf et al., 2005; Bouwman et al., 2009). We highlight the significance of investor, rather than manager, sentiment on merger share price reactions.

The remainder of the paper is structured as follows: Section 2 describes our data. Section 3 discusses the empirical results on the relation between sentiment and the short-term wealth effect of bidders upon their merger announcements. Section 4 concludes.

\section{Data description}

We use daily GNH data from Facebook for seventeen international markets between September 2007 and March 2012 as our main proxy of market sentiment. The countries included are Argentina, Australia, Austria, Belgium, Canada, Germany, India, Ireland, Italy, Mexico, the Netherlands, New Zealand, Singapore, South Africa, Spain, the UK and the US. ${ }^{6}$ The coverage available from Facebook determines the countries selected and the sample period of the study. GNH is estimated by Facebook's Data Team based on the status updates of millions of Facebook users, and the construction of the index is explained in detail in Kramer (2010). GNH is a standardized index estimated by Facebook's Data Team by measuring the percentage of 'positive' and 'negative' terms used in Facebook users' status updates. Using Text Analysis and Word Count (TAWC) programs to identify positive and

\footnotetext{
${ }^{6}$ Note that Facebook offers sentiment data for twenty markets. Chile, Colombia and Venezuela are excluded since no mergers are available within the requested data restrictions.
} 
negative words from the Linguistic Inquiry and Word Count (LIWC) dictionary, GNH is estimated as follows:

$$
\mathrm{GNH}_{i, j}=\frac{x_{p, i}-x_{p, \text { all }}}{\sigma_{p, \text { all }}}-\frac{x_{n, i}-x_{n, \text { all }}}{\sigma_{n, \text { all }}}
$$

where $\mathrm{GNH}_{i, j}$ is the sentiment index of country $j$ at day $i, x_{p, i}$ and $x_{n, i}$ are the average positive $(p)$ and negative $(n)$ words used respectively on day $i$ in the country, and $x_{p, \text { all }}$, $x_{n, \text { all }} \sigma_{p, \text { all }}$, and $\sigma_{n, \text { all }}$ are the average ( $x$ ) positive and negative words used over the duration of the index and the standard deviation ( $\sigma$ ) of those variables. The extreme high and low 10 percent of the days are excluded by Facebook when estimating $x_{p, \text { all }}, x_{n, \text { all }} \sigma_{p, \text { all }}$, and $\sigma_{n, \text { all }}$ to minimize the impact of extreme values. In line with Siganos et al. (2014), we exclude observations above the $99^{\text {th }}$ percentile, since these normally relate to messages like "Happy Mother’s Day”, which do not necessarily reflect sentiment.

We also download from Thomson OneBanker information on acquisitions by bidding firms in corresponding countries within the available data periods. For a deal to be included in the sample, the bidder needs to be listed and to acquire at least 50 percent of the target's shares. We also require the target company size (deal value) to be at least $1 \%$ of the market value of the bidder. These data restrictions are commonly used to identify significant acquisitions in the merger literature (e.g., Moeller et al., 2004). Eligible firms also have available Datastream codes and available returns from Datastream for the interval period from the merger announcement to three days after the day of their bid announcements. At least one of those daily stock returns should be non-zero for a bidding firm to be included in the sample. We use the returns index (RI) datatype from Datastream to incorporate dividend 
payments to calculate log returns, and we proxy market returns for each of the seventeen countries by Datastream’s total market indexes (TOTMK).

Following prior literature, such as Fuller et al. (2002) and Rosen (2006), we calculate abnormal returns as the difference between the return for the bidder and the relevant country index return. To measure the short-term wealth effect, we estimate the cumulative abnormal returns over a four-day period $(0,+3)$. Since small investors are likely more prone to be influenced by sentiment, and it is unlikely that small investors are aware of potential leaks prior to merger announcements, our sentiment and stock returns measures commence at the day of the merger announcement (day 0). We use a three-day lead to fully capture the share price reaction by investors, since small investors may be slow to react to information, and to allow for Facebook users updating their status at any time during the day, even after the closure of the stock markets. ${ }^{7}$ In untabulated results, we find that results are similar and the conclusions consistent when using alternative periods, such as in the shorter three-day event window $(0,+2)$.

While our focus is on the relation between sentiment and bidder abnormal returns, prior research finds that firm and deal characteristics have a significant relation with bidder abnormal returns. Based on the literature, ${ }^{8}$ we therefore also incorporate a number of control variables in the analysis. Prior research suggests that the listing status of targets may affect bidder abnormal returns, and, following Fuller et al. (2002) and Rosen (2006), we classify deals into acquisitions of Public, Private, and Subsidiary firms. Public is a dummy equal to one for public target deals and Private a dummy equal to one for private deals (with Subsidiaries captured by the intercept in the regression analysis). Stock is a dummy equal to

\footnotetext{
${ }^{7}$ Vitrue (2010) reports that Facebook activity peaks at 3pm, and is present after the closure of stock markets.

${ }^{8}$ Studies include those by Asquith et al. (1983), Travlos (1987), Rau and Vermaelen (1998), Sudarsanam and Mahate (2003), Faccio and Masulis (2005), Titman et al. (2004), Draper and Paudyal, (2006), and Danbolt and MacIver (2012).
} 
one for deals with full payment in stock and Cash a dummy equal to one for deals with full cash offers (with Mixed Pay offers captured by the intercept). Larger transactions are likely to have a larger impact on the bidder, and we therefore control for the relative size of the target to the bidder. We incorporate a Relative Size dummy which is equal to one for deals belonging to the top quartile of relative size between bidder and target firms, and zero otherwise.

Other bid characteristics controlled for are the size of the bidder (as captured by the natural logarithm of the market value of equity, LnMV); the bidder's book-to-market-ratio (BTMV); domestic versus cross-border acquisitions (with Domestic a dummy variable taking the value of one for domestic deals); whether the acquisition is focused or diversifying (with diversifying being a dummy variable equal to one where targets and bidders do not share the same first two-digit SIC code); whether the transaction is competitive or whether there is a single bidder for the target (with Competitive being a dummy equal to one for multiple bidders according to SDC); and for tender offers versus mergers (with Tender being a dummy equal to one for tender offers). Following e.g., Faccio and Masulis (2005) and Karampatsas et al. (2014), we use the pre-bid run-up in the bidder's market-adjusted returns to capture possible market overvaluation of the bidder. CARs $-252,-20$ is the cumulative abnormal returns over the period from -252 to -20 days prior to each merger announcement. As financial strength and capital structure may affect the method of payment used (Karampatsas et al., 2014), we incorporate DebtTA, which is long-term debt plus current liabilities to total assets, and CashFlow, which is measured as operating income before depreciation, interest expenses, taxes, and dividends to total assets.

Table 1 shows summary descriptive statistics of sentiment and the share price reaction of bidders around their merger announcements. We find that close to half of the acquisitions 
took place in the US (3,525 out of a total of 7,529 acquisitions in our sample). Due to the small number of acquisitions available in some countries, we present empirical results for all countries combined and, in a later section, for US and non-US acquisitions separately. In line with prior literature (e.g., Travlos, 1987; Chang, 1998; Draper and Paudyal, 2006), we find that the short-term wealth effect tends to be positive for bidders in acquisitions of private firms and negative in acquisitions of publicly listed targets. For example, the four-day cumulative abnormal returns are -0.7 and 2.0 percent for the sample as a whole for public and private target acquisitions, respectively. We also estimate the mean GNH for the equivalent interval period from the merger announcement day to three days after. With the exclusion of extreme positive days (such as “Happy Mother’s Day”), mean GNH tends to be negative, although there are some national variations, with India experiencing the lowest average GNH $(-0.058)$ and Italy the highest $(0.014)$ around the time of the acquisition announcements. ${ }^{9}$ Our descriptive statistics for GNH are similar to those reported by Siganos et al. (2014). In the cross-sectional regressions, standard errors are clustered by country (Petersen, 2009), and fixed effects by country are also included to control for such variations.

\section{[please insert Table 1 here]}

Table 2 offers Pearson correlations of the variables used in the study. The correlation coefficient between the GNH variable and abnormal returns is positive and statistically significant at the $5 \%$ level, offering the first indication of sentiment having a significant relation with bidder abnormal returns. In line with the literature (e.g., Sudarsanam and Mahate, 2003), abnormal returns are also related with the control variables used, and some of

\footnotetext{
${ }^{9}$ It should be noted that the GNH is on average similar on bid and on non-bid dates, and in probit analysis of the relation between bid announcement and either current or past levels of GNH, we find no indication of the timing of bid announcements being related to the level of GNH. Given the time and effort involved in planning and executing takeover bids, it is unlikely that managers would time the announcements based on small variations in market sentiment.
} 
the control variables are correlated. There is, however, no issue of collinearity (as the highest correlation coefficient is less than 0.48), and the significant correlations among the control variables are acceptable for the purpose of the study, since we are not focusing on the relation of each control variable with abnormal returns, but rather on whether GNH is related to bidder announcement returns after controlling for potential variables that are related with companies’ stock returns. The following section explores whether GNH is related with bidder announcement returns.

[please insert Table 2 here]

\section{Empirical results}

\subsection{Sentiment and bidder announcement returns: Univariate results}

We first undertake univariate analysis to explore the relation between GNH and bidder announcement returns. Note that GNH and returns are measured over the same interval period between day 0 and +3 after each merger announcement day. We first rank mergers based on the level of GNH over the event window and then split the sample of acquisitions into quartiles. Quartiles, rather than e.g. deciles, are used to ensure that portfolio returns do not arrive from a small number of observations.

Table 3 shows the cumulative abnormal portfolio returns around the merger announcements across different levels of GNH portfolios. We find that GNH is significantly related to bidder stock returns. For example, bidder abnormal returns are 2.06 and 0.92 percent for high and low GNH portfolios, respectively, when analyzing the full sample of countries. The difference is economically large and statistically significant at the $1 \%$ level. Moving from high to lower GNH portfolios, mean returns for bidders for the overall sample 
of all countries are as follows: $2.06 \%, 1.78 \%, 2.01 \%$, and $0.92 \%$. These results offer initial support for our main hypothesis that sentiment is related with bidder returns, with acquisitions undertaken on days with high market sentiment associated with higher announcement abnormal returns.

$$
\text { [please insert Table } 3 \text { here] }
$$

\subsection{Sentiment and bidder announcement returns: Multivariate results}

Prior research on mergers and acquisitions highlights the impact of bid and firm characteristics on bidder returns, and we therefore undertake multivariate analysis to test whether the relation between sentiment and bidder CAR holds once we control for variables that may impact on bidder abnormal returns. We estimate OLS regressions with robust standard errors clustered by country, and country-fixed effects are included. The dependent variable is the four-day cumulative abnormal returns per firm $(0,+3)$. The key independent variable is GNH in the contemporaneous period with that used for abnormal returns, and the following control variables are also employed: the logarithmic market cap of the bidder, public and private acquisition dummy variables (with subsidiaries captured by the intercept), stock and cash payment dummies (with mixed payment captured by the intercept), a relative size dummy for deals in the top quartile, book-to-market ratio, a domestic acquisition dummy, a diversified dummy based on whether the bidder and target firms do not share the same two-digit SIC code industries, a competitive bid dummy if there are multiple bidders, a tender offer dummy, the cumulative run-up returns prior to merger announcements (CARs252,-20), the ratio of debt to total assets, and cashflows. We include eight one-day lags (for days -8 to -1 ) of GNH to ensure that prior sentiment levels could not be used to predict the next period's sentiment, and, similarly, eight-day lags of each country's stock market returns to 
control for potential reverse causality, with prior gains/losses in stock markets influencing investors' happiness. Eight lags are selected, since in untabulated results we find that there is statistically significant daily autocorrelation for GNH up to a maximum of eight lags, and the same selection of lags are used for prior stock market returns, for consistency. ${ }^{10}$ The parameter coefficients of country dummies, and those on lags of GNH and on lags of stock market returns, are not reported for space considerations.

Table 4 shows the results of the multivariate analysis. We find that sentiment remains positively related with bidder returns. Column (1) shows that the parameter coefficient on GNH is 0.120 , with a p-value equal to 0.003 , indicating that after controlling for other factors, a one percentage point increase in GNH is associated with a 0.120 percentage point increase in bidder cumulative abnormal returns. Note that bidder stock returns are in excess of the contemporaneous stock market returns, indicating that the relation reported in this study is beyond the stock market returns and sentiment relation previously reported in the literature. In untabulated results, we find that the parameter coefficient for GNH is 0.147 and 0.267 when regressing GNH with stock market returns and bidder returns, respectively (both significant at the $1 \%$ level). Note that the difference between 0.267 and 0.147 is the bidder stock returns in excess of stock market returns reported earlier (0.120). The relation between bidder stock returns and sentiment is therefore much more prominent at the time of their bid announcement than the general relation between sentiment and stock returns reported in conventional behavioral studies. Our results are consistent with what we would expect if investors' subconscious reaction to potential synergies and risks involved with mergers is associated with sentiment, with happy investors tending to overestimate potential synergies and/or underestimate the risks involved with the mergers.

\footnotetext{
${ }^{10}$ In untabulated results, we also use five-day lags for both GNH and stock market returns to capture potential weekly cycles. Results remain very similar in alternative lag selections.
} 
As a further test of whether the relation between sentiment and stock returns is particularly strong during acquisitions, when the value of bidders is arguably more uncertain than usual, we use the same model to test the relation between sentiment and share returns in a period prior to the bid announcement, when the forthcoming bid is still not known to investors. Column (2) of Table 4 shows the parameter coefficients when regressing bidder abnormal stock returns during the interval period between -12 and -10 days prior to each merger announcement on contemporaneous GNH and the same control variables. We find that the parameter coefficient for GNH for the -12 and -10 interval period is insignificant, highlighting the existence of the relation only during the merger announcement period. A Chow test (Chow, 1960) that compares the parameter coefficient for GNH between the prebid and merger announcement periods, reported in Column (3) of Table 4, shows that the coefficient for GNH is significantly higher at the $1 \%$ level in the merger period.

Note that the signs of the parameter coefficients for control variables are generally in line with prior literature (e.g., Travlos, 1987; Draper and Paudyal, 2006). We find bidder abnormal returns to be higher in acquisitions of subsidiaries than in acquisitions of private targets, with bidder abnormal returns particularly low in acquisitions of publicly listed targets. With the mix of public and private targets in the sample, it is not unexpected that we find bidder abnormal returns on average slightly higher in share than in cash financed acquisitions. Consistent with prior literature, we find bidder returns to be higher in tender offers than in mergers, but, contrary to expectations, also higher in competitive bidding contests. ${ }^{11}$ We find some evidence of reversal, with bidder abnormal returns being

\footnotetext{
${ }^{11}$ Draper and Paudyal (2006) find that bidder returns depend on both the listing status of the target and the method of payment; they find returns to acquirers of publicly listed targets to be worse in share than in cash financed acquisitions, but that bidders earn higher abnormal returns when paying in stock than with cash in acquisitions of private targets.
} 
significantly lower where there has been a substantial run-up in the bidder's share price prior to the bid. Bidder returns are also influenced by gearing levels and cash flow balances.

[please insert Table 4 here]

\subsection{Is the relation between sentiment and bidder returns irrational?}

We next explore whether the relation between sentiment and bidder returns is the result of a short-term market overreaction. To test this, we explore the relation between sentiment and bidder announcement abnormal returns over the days following a merger announcement. If the relation between sentiment and bidder announcement returns is driven by an irrational reaction, the relation is expected to reverse as traders less susceptible to sentiment (such as merger arbitrageurs) take advantage of the market mispricing.

Table 5 shows the parameter coefficients of GNH when we estimate the relation between GNH, as estimated previously in the interval period between 0 and +3 days, and its relation with bidder returns over the following +4 to +12 days after each merger announcement. Due to space considerations, we only report the parameter coefficients for GNH on each day, although all control variables used earlier are included in the regressions. We find that the relation of sentiment with bidder announcement returns is significantly negative on day $+4(-0.072$ and significant at the $1 \%$ level), which is to an extent comparable, although slightly smaller than the initial over-reaction $(0.120)$. The relation then remains mostly insignificant for the remaining lead days. Merger arbitrageurs trade heavily around merger announcements, and therefore the response to misevaluations due to sentiment is expected to be immediate. However, since professional investors are still prone to behavioral biases (Kaplanski and Levy, 2013; Kling and Gao, 2008; Gleijser and Heyndels, 2001), albeit 
to a lesser extent than other market participants, a full recovery to the initial stock prices may not be expected to show up empirically.

[please insert Table 5 here]

\subsection{What drives the relation between sentiment and bidder returns?}

This section explores characteristics that drive the relation between sentiment and bidder returns. First, we hypothesize that the relation is more prominent in firms with a low percentage of shares owned by large blockholders, since smaller investors are likely to be more heavily influenced by sentiment (e.g., DeLong et al., 1990). ${ }^{12}$ Second, we hypothesize that the relation between sentiment and bidder returns is stronger within public deals, since there is a higher likelihood for the merger announcement to attract more attention in public deals. Third, we test whether the first two factors interact. If sentiment affects predominately private investors and deals with significant publicity, we expect the relation between sentiment and bidder returns to be particularly high in acquisitions of public targets by bidders with low levels of blockholder ownership. Fourth, we explore the influence of relative size on the magnitude of the sentiment and return relation. Larger deals can be expected to have a larger impact on the bidder, and therefore the sentiment and return relation should be more pronounced within large-size deals.

Panel A of Table 6 shows the univariate results in sub-groups where a more/less pronounced relation with sentiment is expected. Blockholder captures the total percentage of

\footnotetext{
${ }^{12}$ Note that we control for the size of the acquirer in multivariate analysis to ensure that our results are not driven by blockholder ownership being negatively correlated with firm size.
} 
shares held by strategic investors who each hold a large stake. ${ }^{13}$ To explore whether GNH has a stronger relation with abnormal returns for companies with higher proportions of smaller investors, who may be more susceptible to behavioral biases than larger and more sophisticated investors, we use a Low Blockholder dummy variable that takes the value of one if blockholder ownership is less than $5 \%$, and zero otherwise. ${ }^{14}$ We also split the sample into high and low relative size groups based on quartiles. We first identify the top and bottom portfolio for each characteristic and then rank them based on GNH.

Results support the developed hypotheses. In particular, we find that the relation between GNH and bidder returns is more pronounced in companies with low rather than high blockholder ownership. The difference in returns between high and low GNH by bidders with low levels of blockholder ownership is 1.45 percentage points and significant at the $1 \%$ level, compared to an insignificant 0.39 percentage points in acquisitions by bidders with counterpart high levels of blockholder ownership. ${ }^{15}$ The difference in returns between high and low GNH deals is also $2.81 \%$ and significant at the $1 \%$ significance level for public deals, and $0.75 \%$ and insignificant for private deals. The difference between high and low GNH for public targets of low blockholder ownership deals is a significant 3.23 percentage points, while we find no relation between GNH and bidder returns in acquisitions of private targets. Finally, the high minus low GNH difference in returns is 3.08\% for high relative size transactions, and significant at the $1 \%$ level, and an insignificant $0.56 \%$ for low relative size transactions.

\footnotetext{
${ }^{13}$ Regulations vary slightly between countries as to what stakes have to be reported to the stock exchange. For example, in the US stakes above $5 \%$ have to be reported, while in the UK the threshold is $3 \%$. Given the different reporting requirements in different countries, we use a $5 \%$ cut-off to identify blockholder ownership.

${ }^{14}$ In untabulated results, we find that alternative blockholder ownership definitions, such as using a dummy variable that equals one for ownership of less than $10 \%, 15 \%$, and $20 \%$, offers similar empirical results.

${ }^{15}$ In untabulated results, we also test the trading volume around the announcement of the deals and find that firms with both high and low blockholder ownership experience positive and significant abnormal trading activity around merger announcements. The difference in the relation between GNH and bidder announcement returns between the two groups is therefore unlikely to be driven by thin trading.
} 
For completeness, and to ensure that sentiment is related with stock returns, we also explore whether the relation between GNH and bidder abnormal returns also varies with the method of payment and the size of the bidder. Univariate results in relation to high and low GNH levels on the following subgroups: cash, stock and mixed methods of payment, and large and small size of bidding firms, are reported in Panel B of Table 6. We have no expectation as to whether the relation between investor sentiment and bidder abnormal returns will vary with the method of payment or firm size. We find that the relation between GNH and stock returns overall holds across the alternative subgroups. The difference in abnormal returns between high and low GNH states is, however, not quite statistically significant in stock financed deals (p-value equal to 0.119), although the coefficient is economically significant at $2.66 \%$. The lack of significance may be attributable to the relatively small number of stock financed deals available.

\section{[please insert Table 6 here]}

Table 7 shows the multivariate results, focusing on blockholder, target status, and the relative size of the acquisitions that we earlier developed hypotheses for. We construct dummy variables for each group of interest and interact them with GNH. We find that our univariate results hold within multivariate analysis. In regression 1, we find the absence of a blockholder to have a small and insignificant relation with bidder abnormal returns. However, more importantly, the large positive parameter coefficient $(0.281)$ for the interactive variable LowBlock*GNH (significant at the 1\% level) indicates that the relation between GNH and bidder abnormal returns is more pronounced for the group of bidders where blockholders own a smaller fraction of shares. This is consistent with our prediction that smaller and arguably less sophisticated investors may be more susceptible to the influence of sentiment. 
The positive parameter coefficient $(0.276)$ for the interactive variable Public*GNH (also significant at the 1\% level) in the second regression supports the argument that the influence of GNH on bidder returns is more pronounced for acquisitions of public target firms. In the third regression we look at the interaction between these two effects. As predicted, we find the relation of sentiment to be particularly large (coefficient of 0.477 and significant at the $10 \%$ level) in acquisitions of public targets by bidders with low blockholder ownership. Note that when we interact LowBlock*Private*GNH and LowBlock*Private, both parameter coefficients are insignificant, highlighting the significance of the public dummy on the magnitude of the relation between sentiment and bidder stock returns.

In the final regression, we study the relation between relative size and bidder stock returns. Not only do we find bidder abnormal returns to be higher where the acquisition is large relative to the size of the target (regression coefficient of 0.021 and significant at the $1 \%$ level), but the relation between sentiment and bidder stock returns (as captured by the interactive variable RelSizeHigh*GNH) is also significantly higher in acquisitions of relatively large targets. The regression coefficient of 0.462 is again significant at the $1 \%$ level. This is consistent with our expectations of a multiplier effect, with any error in target valuation by investors (overestimation of synergies or underestimation of risks) associated with sentiment biases having a stronger relation with bidder returns the larger the relative size of the target.

[please insert Table 7 here]

\subsection{Results for US and non-US mergers}

Results above are estimated for the pooled sample of all seventeen countries. Due to the importance of the US market in global M\&A activity and the availability of an alternative 
daily proxy of sentiment for this market, we re-estimate prior multivariate results for the subsample of US acquisitions, and the remaining sub-sample of non-US acquisitions. ${ }^{16}$ However, there are also reasons to expect the relation between sentiment and bidder returns to vary between markets, particularly with regard to public deals, where we would expect different results in US versus non-US mergers. ${ }^{17}$ We hypothesize above that mergers with public targets experience a more pronounced relation with sentiment due to media coverage that particularly influences the investment decisions of small investors. However, the depth of media coverage of a topic may vary significantly from one country to another. Wu (2000) compares news coverage of the same international news within 38 countries, and finds that US coverage captures news by far the most comprehensively. US media is found to capture $18 \%$ of the media space, with France, in second place, having merely $9 \%$. Therefore, we hypothesize that the relation between sentiment and bidder stock returns is more pronounced in acquisitions of US public targets than in acquisitions of public firms in other markets. Note that the control variables used in this section are the same as those used in the multivariate analysis above, but we only report the parameter coefficients of interest for space considerations.

Table 8 shows the results for the relation between US-GNH and bidder announcement returns as well as the results for characteristics found earlier to be related with the strength of the relation between key variables under study. We find that US results are relatively similar to those found for the full sample. US-GNH is positively related with returns $(0.115)$, although slightly statistically insignificant, as shown in regression 1 . The relation between US-GNH and returns is more prominent within firms with a low percentage of blockholder

\footnotetext{
${ }^{16}$ In untabulated results, we find that US univariate results show the same trends in line with reported multivariate results.

17 The limited number of mergers in several countries also restricts the extent to which detailed cross-country comparisons can be undertaken.
} 
ownership (regression 2), in acquisitions of public targets (regression 3), when the two characteristics are interacted (regression 4), and in high relative size acquisitions (regression 5).

\section{[please insert Table 8 here]}

An alternative daily sentiment index is available for the US - the Gallup Economic Confidence index. We use this to explore whether our results hold when using an alternative daily sentiment index. Note that the sample period is shorter than in the main analysis, as Gallup’s Index data commence in January 2008 (while GNH goes back to September 2007). In short, the Gallup Index is calculated based on phone interviews with 1,500 Americans aged 18 or over, during which interviewees are asked to rate their expectations for the future. In untabulated results, we find that the Pearson correlation between US-Gallup and US-GNH is 0.390 and significant at the $1 \%$ level, giving the first indication that similar results may be obtained for both indexes. Table 9 shows multivariate results when using US-Gallup. We find that with the use of US-Gallup, we arrive at qualitatively similar conclusions to those obtained using US-GNH, showing that our previous results are not driven by the use of the GNH proxy. In particular, we find that there is a positive relation between US-Gallup and bidder announcement returns. The parameter coefficient on US-Gallup is 0.055, which is significant at the $1 \%$ level. The relation between US-Gallup and bidder returns is also more prominent for bidders with low blockholder ownership, in acquisitions of public targets, in the interaction of low ownership and acquisition of public target firms, and in high relative target size deals.

[please insert Table 9 here]

We further explore non-US results in Table 10. In line with results for the US and the full sample of countries, NonUS-GNH is positively related with returns (0.110) and 
significant at the 5\% level. Also, the relation between NonUS-GNH and returns is more prominent within firms with a low percentage of blockholder ownership, and in high relative size acquisitions. However, the parameter coefficients regarding acquisitions of public targets are insignificant, possibly due to the lower level of media coverage of financial news in less developed countries in relation to the US market ( $\mathrm{Wu}, 2000)$. In untabulated results, we support that sentiment is related with bidder abnormal announcement returns more prominently in public targets of other highly developed countries (in addition to the US market), such as within a number of European countries. These results offer an international dimension of the significance of media coverage in public acquisitions.

$$
\text { [please insert Table } 10 \text { here] }
$$

\section{Conclusion}

While a number of factors have been previously put forward to explain bidder returns, little empirical investigation has been undertaken on the significance of behavioral aspects. We use a direct measure of daily sentiment data available from Facebook across seventeen international markets to capture sentiment on the days surrounding mergers and explore its relation with bidder announcement abnormal returns. We argue that investors are subconsciously influenced by their sentiment, which may bias their estimation of expected synergies and risks from mergers; therefore, sentiment is expected to be related with bidder announcement returns.

Prior literature (e.g., Siganos et al., 2014) has found a positive relation between sentiment and the general stock market index, and we similarly find such a relation. However, our study goes beyond the conventional relation between sentiment and stock returns by focusing on the relation between sentiment and bidders' abnormal returns at the 
time of the bid announcement. By controlling for the 'normal' relation between sentiment and share returns, we thus capture the extent to which the relation between sentiment and share returns is different during acquisition periods compared to other times. Given that acquisitions are generally large investments, any behavioral biases in investors' assessment of synergies or risks may be expected to have a significant impact on firm value. We find empirical evidence of sentiment being positively related with bidder announcement abnormal returns. The relation analyzed in this study goes beyond the conventional relation between sentiment and stock market returns reported by earlier behavioral studies, since bidder stock returns are market-adjusted. The relation is only present during the merger period, while the relation is insignificant when testing within a period prior to merger announcements. We also find that the relation between sentiment and bidder returns is higher for bidders with low levels of blockholder ownership, consistent with predictions that smaller investors and less informed traders are more susceptible to behavioral biases, especially in acquisitions which are more likely to attract significant media attention. The effect is also larger in acquisitions of public targets within US markets with significant media coverage, and in acquisitions of relatively large targets. Our evidence suggests that the relation between sentiment and bidder abnormal returns is the outcome of irrational behavior. Sentiment appears to influence investors' assessment of expected synergies and risks involved in an acquisition. We conclude that sentiment is an important factor to control for when exploring bidder announcement abnormal returns. 


\section{References}

Asquith, P., Bruner, F., Mullins, D., 1983. The gains to bidding firms from merger. J. Financ. Econ. 11, 121-139.

Barber, M., Odean, T., 2008. All that glitters: The effect of attention and news on the buying behavior of individual and institutional investors. Rev. Financ. Stud. 21, 786-818.

Bless, H., Gerald, L., Clore, N., Schwarz, V., Rabe, C., Wolk, M., 1996. Mood and the use of scripts: Does being in a happy mood really lead to mindlessness? J. Pers. and Soc. Psych. 71, 665-679.

Bouwman, C.H.S., Fuller, K., Naoin, A., 2009. Market valuation and acquisition quality: Empirical evidence, Rev. Financ. Stud. 22, 633-679.

Chang, S., 1998. Takeovers of Privately Held Targets, Methods of Payment, and Bidder Returns. J. Finance 53, 773-784.

Chow, G., 1960. Tests of Equality Between Sets of Coefficients in Two Linear Regressions. Econ. 28, 591-605.

Danbolt, J., MacIver, G., 2012. Cross-Border versus Domestic Acquisitions and the Impact on Shareholder Wealth, J. Bus. Fin. \& Acc. 39, 1028-1067.

DeLong, B., Shleifer, A., Summers, L., Waldmann, R., 1990. Noise trader risk in financial markets. J. Polit. Econ. 98, 703-738.

Draper, P., Paudyal, K., 2006. Acquisitions: private versus public. Europ. Financ. Manag. 12, 57-80.

Eckbo, N.E., 2009. Bidding strategies and takeover premiums: A review. J. Corp. Fin. 16, 149-178.

Edmans, A., Garcia, D., Norli, O., 2007. Sport sentiment and stock returns. J. Finance 4, 1967-1998.

Faccio, M., Masulis, R., 2005. The choice of payment method in European mergers and acquisitions. J. Finance 60, 1345-1388.

Fama, E.F., 1970. Efficient capital markets: A review of theory and empirical work. J. Finance 25, 383-417. 
Fang, L., Peress, J., 2009. Media coverage and the cross-section of stock returns. J. Finance 64, 2023-2052.

Fuller, K., Netter, J., Stegemoller, M., 2002. What do returns to acquiring firms tell us? Evidence from firms that make many acquisitions. J. Finance 57, 1763-1793.

Glejser, H., Heyndels, B., 2001. Efficiency and inefficiency in the ranking in competitions: The case of the Queen Elisabeth Music Contest. J. Cult. Econ. 25, 109-129.

Hirshleifer, D., Shumway, T., 2003. Good day sunshine: stock returns and the weather. J. Finance 58, 1909-1932.

Johnson, E., Tversky, A., 1983. Affect, generalization, and the perception of risk. J. Pers. and Soc. Psych. 45, 20-31.

Kaplanski, G., Levy, H., 2010. Sentiment and stock prices: The case of aviation disasters. J. Financ. Econ. 95, 174-201.

Kaplanski, G., Levy, H., 2013. Are analysts affected by sentiment? Working paper.

Kaplanski, G., Levy, H., Veld, C., Veld-Merkoulova, Y., 2014. Do happy people make optimistic investors? J. Financ. Quant. Anal. (forthcoming).

Karabulut, Y., 2013. Can Facebook predict stock market activity? Working paper.

Karampatsas, N., Petmezas, D., Travlos, N., 2014. Credit ratings and the choice of payment method in mergers and acquisitions. J. Corp. Finance, 25, 474-493.

King, M., 2009. Prebid run-ups ahead of Canadian takeovers: How big is the problem? Financ. Manag. Winter: 699-726.

Kling, G., Gao, L., 2008. Chinese institutional investors' sentiment. Int. Financ. Markets, Inst. and Money 18, 374-387.

Kramer, A., 2010. An unobtrusive behavioral model of Gross National Happiness, Proceedings CHI. ACM Press, 287-290.

Kramer, A., Chung, K., 2011. Dimensions of self-expression in Facebook status updates. Proceedings of the 5th international AAAI Conference on Weblogs and Social Media.

Kramer, A.D.I., Guillory, J.E., Hancock, J.T., 2014. Experimental evidence of massive-scale emotional contagion through social networks. Psych. Cogn. Sci., 111, 8788-8790.

Kuchler, H., 2014. Facebook clicks on the ‘buy’ button. Financial Times 19/20 July, 14. 
Lemmon, M., Portniaguina, E., 2006. Consumer confidence and asset prices: Some empirical evidence. Rev. Financ. Stud. 19, 1499-1529.

Loewenstein, G., Elke, F., Weber, U., Hsee, C., Welch, N., 2001. Risk as feelings. Psych. Bullet. 127, 267-286.

Mitchell, R., Phillips, L., 2007. The psychological, neurochemical and functional neuroanatomical mediators of the effects of positive and negative mood on executive functions. Neuropsychologia 45, 617-629.

Moeller, S., Schlingemann, F., Stulz, R., 2004. Firm size and the gains from acquisitions. J. Financ. Econ. 73, 201-228.

Officer, M.S., 2007. Are performance based arbitrage effects detectable? Evidence from merger arbitrage. J. Corp. Finance 13, 793-812.

Palomino, F., Renneboog, L., Zhang, C., 2009. Information salience, investor sentiment, and stock returns: The case of British soccer betting. J. Corp. Finance 15, 368-387.

Petersen, M.A., 2009. Estimating standard errors in finance panel data set: Comparing approaches. Rev. Financ. Stud. 22, 435-480.

Rau, P., Vermaelen, T., 1998. Glamour, value and the post-acquisition performance of acquiring firms. J. Financ. Econ. 49, 223-253.

Rhodes-Kropf, M., Viswanathan, S., 2004. Market valuation and merger waves. J. Finance $59,2685-2718$

Rhodes-Kropf, M., Robinson, D.T., Viswanathan, S., 2005. Valuation waves and merger activity: The empirical evidence. J. Financ. Econ. 77, 561-603.

Rosen, R.J., 2006. Merger momentum and investor sentiment: The stock market reaction to merger announcements, J. Business. 79, 987-1017.

Shleifer, A., Vishny, R., 2003. Stock market driven acquisitions. J. Financ. Econ. 70, 295311.

Siganos, A., Vagenas-Nanos, E., Verwijmeren, P., 2014. Facebook’s daily sentiment and international stock markets, J. Econ. Behav. Organ. 107, 730-743.

Sudarsanam, S., Mahate, A., 2003. Glamour acquirers, method of payment and postacquisition performance: The U.K. evidence. J. Bus. Finance Acc. 30, 299-341. 
Titman, S., Wei, K., Xie, F., 2004. Capital investments and stock returns. J. Financ. Quant. Anal. 39, 677-700.

Travlos, N., 1987. Corporate takeover bids, methods of payment, and bidding firms stock returns. J. Finance 42, 943-963.

Vitrue, 2010. Managing your Facebook community: Findings on conversation volume by day of week, hour and minute. White paper.

Wright, W., Bower, G., 1992. Mood effects on subjective probability assessment. Organ. Behav. Human Dec. Proc. 52, 276-291.

Wu, H., 2000. Systemic determinants of international news coverage: A comparison of 38 countries. J. Comm. 50, 110-130. 
Table 1. Descriptive statistics

This table shows the descriptive statistics of the number of mergers, the sentiment level (GNH), and the percentage cumulative abnormal returns (CARs) per country in the sample. Sentiment and cumulative returns are estimated over the four-day period from the merger announcement day to three days after $(0,+3)$. $\mathrm{N}$ indicates the number of merger transactions analyzed. $* * *$, and $* * *$ indicate significance at the 10,5 , and 1 percent levels, respectively.

\begin{tabular}{|c|c|c|c|c|c|c|c|c|c|c|c|c|}
\hline & \multirow[b]{2}{*}{$\operatorname{GNH}(0,+3)$} & \multirow[b]{2}{*}{$\mathrm{N}$} & \multirow[b]{2}{*}{ p-value } & \multicolumn{2}{|l|}{$\operatorname{CARs}(0,+3)$} & \multirow{2}{*}{$\begin{array}{c}\text { CARs }(0,+3) \\
\text { Median }\end{array}$} & \multicolumn{3}{|c|}{ Public } & \multicolumn{3}{|c|}{ Private } \\
\hline & & & & Average & p-value & & $\operatorname{CARs}(0,+3)$ & $\mathrm{N}$ & p-value & $\operatorname{CARs}(0,+3)$ & $\mathrm{N}$ & p-value \\
\hline All & $-0.013^{* * *}$ & 7529 & 0.000 & $0.017 * * *$ & 0.000 & 0.007 & $-0.007 * *$ & 1059 & 0.029 & $0.020 * * *$ & 3852 & 0.000 \\
\hline Argentina & -0.007 & 14 & 0.432 & 0.011 & 0.614 & 0.027 & -0.004 & 3 & 0.970 & -0.004 & 6 & 0.890 \\
\hline Australia & $-0.009 * * *$ & 733 & 0.000 & $0.033 * * *$ & 0.000 & 0.013 & 0.000 & 102 & 0.971 & $0.042 * * *$ & 397 & 0.000 \\
\hline Austria & $-0.014^{* * *}$ & 31 & 0.000 & 0.005 & 0.585 & -0.002 & 0.004 & 3 & 0.935 & 0.002 & 14 & 0.813 \\
\hline Belgium & $-0.005 *$ & 70 & 0.055 & $0.015^{* * *}$ & 0.006 & 0.010 & 0.011 & 6 & 0.741 & $0.016^{* *}$ & 34 & 0.032 \\
\hline Canada & $-0.012 * * *$ & 1299 & 0.000 & $0.023^{* * *}$ & 0.000 & 0.005 & -0.010 & 283 & 0.149 & $0.033^{* * *}$ & 606 & 0.000 \\
\hline Germany & $-0.003^{*}$ & 119 & 0.088 & 0.009 & 0.118 & 0.012 & -0.007 & 20 & 0.577 & 0.004 & 48 & 0.705 \\
\hline India & $-0.058 * * *$ & 23 & 0.000 & 0.020 & 0.211 & 0.013 & 0.034 & 2 & 0.552 & 0.016 & 14 & 0.487 \\
\hline Ireland-Rep & $-0.025 * * *$ & 62 & 0.000 & 0.015 & 0.231 & 0.019 & -0.041 & 2 & 0.578 & 0.010 & 33 & 0.493 \\
\hline Italy & $0.014^{* * *}$ & 127 & 0.000 & 0.003 & 0.451 & 0.002 & $-0.029 * *$ & 11 & 0.028 & 0.003 & 53 & 0.725 \\
\hline Mexico & -0.006 & 16 & 0.257 & 0.017 & 0.238 & 0.016 & 0.018 & 5 & 0.571 & -0.002 & 5 & 0.899 \\
\hline Netherlands & $-0.016^{* * *}$ & 91 & 0.000 & 0.002 & 0.783 & -0.003 & -0.026 & 19 & 0.157 & 0.001 & 36 & 0.892 \\
\hline New Zealand & $-0.013^{* * *}$ & 28 & 0.000 & 0.022 & 0.266 & 0.000 & -0.027 & 3 & 0.556 & 0.048 & 13 & 0.139 \\
\hline Singapore & $-0.009 * * *$ & 120 & 0.000 & 0.012 & 0.169 & 0.003 & 0.032 & 6 & 0.395 & 0.023 & 48 & 0.136 \\
\hline South Africa & $-0.016^{* * *}$ & 49 & 0.000 & $0.028 * * *$ & 0.008 & 0.006 & $0.071^{*}$ & 5 & 0.084 & 0.029 & 24 & 0.100 \\
\hline Spain & $-0.008^{*}$ & 68 & 0.050 & -0.004 & 0.455 & -0.004 & -0.026 & 10 & 0.110 & -0.009 & 25 & 0.424 \\
\hline UK & $-0.014^{* * *}$ & 1152 & 0.000 & $0.016 * * *$ & 0.000 & 0.010 & -0.003 & 101 & 0.753 & $0.016 * * *$ & 695 & 0.000 \\
\hline US & $-0.016 * * *$ & 3525 & 0.000 & $0.013 * * *$ & 0.000 & 0.007 & $-0.008 *$ & 477 & 0.091 & $0.014 * * *$ & 1801 & 0.000 \\
\hline
\end{tabular}


Table 2. Correlation Matrix

This table shows Pearson correlations of the variables used in the study. CARs and GNH are the percentage cumulative abnormal returns and the sentiment in the interval period between the merger announcement and three days after $(0,+3)$. LnMV is the natural log of the market capitalization of bidders on the merger announcement, Public is a dummy equal to one for public target deals, Private is a dummy equal to one for private deals, Stock is a dummy equal to one for stock payments, Cash is a dummy equal to one for cash-offered deals, RelSize is a dummy equal to one for deals in the top quartile of relative size between bidder and target firms, BTMV is the book-to-market-ratio, Domestic is a dummy variable taking the value of one for domestic deals, Diversified is a dummy variable equal to one where targets and bidders have different two-digit SIC codes, Competitive is a dummy equal to one for multiple bidders according to SDC, Tender is a dummy equal to one for tender offers, CARs 252 ,-20 is the cumulative excess abnormal returns prior to each merger announcement, DebtTA is long-term debt plus current liabilities to total assets, and Cashflow is operating income before depreciation, interest expenses, taxes, and dividends to total assets. Correlations shown are for the full sample of seventeen countries *, **, and *** indicate significance at the 10 , 5 , and 1 percent levels, respectively.

\begin{tabular}{|c|c|c|c|c|c|c|c|c|c|c|c|c|c|c|c|}
\hline & (1) & (2) & (3) & (4) & (5) & (6) & (7) & (8) & (9) & (10) & (11) & (12) & (13) & (14) & (15) \\
\hline \multicolumn{16}{|l|}{ (1) CARs $(0,+3)$} \\
\hline (2) $\mathrm{GNH}(0,+3)$ & $0.030 * *$ & & & & & & & & & & & & & & \\
\hline (3) LnMV & $-0.171^{* * *}$ & -0.013 & & & & & & & & & & & & & \\
\hline (4) Public & $-0.095 * *$ & -0.000 & $0.154^{* * *}$ & & & & & & & & & & & & \\
\hline (5) Private & $0.030^{* *}$ & $-0.034 * * *$ & $-0.192 * * *$ & $-0.414 * * *$ & & & & & & & & & & & \\
\hline (6) Stock & $0.044 * * *$ & 0.006 & $-0.229 * * *$ & $0.340 * * *$ & $-0.093^{* * *}$ & & & & & & & & & & \\
\hline (7) Cash & $-0.028 * *$ & -0.014 & $0.212^{* * *}$ & 0.004 & $-0.084 * * *$ & $-0.232 * * *$ & & & & & & & & & \\
\hline (8) RelSize & $0.123^{* * *}$ & 0.005 & $-0.210 * * *$ & -0.003 & $0.026^{* *}$ & $0.113 * * *$ & $-0.051 * * *$ & & & & & & & & \\
\hline (9) BTMV & $0.067 * * *$ & $0.038 * * *$ & $-0.211 * * *$ & $0.026^{* *}$ & $-0.026 * *$ & $0.108^{* * *}$ & $-0.058 * * *$ & $0.269 * * *$ & & & & & & & \\
\hline (10) Domestic & -0.016 & $-0.035 * * *$ & $-0.081 * * *$ & $0.069 * * *$ & 0.014 & $0.064 * * *$ & $-0.036 * * *$ & 0.007 & $0.035^{* * *}$ & & & & & & \\
\hline (11) Diversified & 0.001 & $0.021^{*}$ & $0.031 * * *$ & $-0.123 * * *$ & $0.062 * * *$ & $-0.093 * * *$ & $0.032 * * *$ & 0.006 & $-0.020 *$ & 0.013 & & & & & \\
\hline (12) Competitive & 0.001 & $0.022^{*}$ & $0.060 * * *$ & $0.198 * * *$ & $-0.084 * * *$ & $0.045 * * *$ & $0.024 * *$ & -0.005 & -0.004 & -0.006 & $-0.033 * * *$ & & & & \\
\hline (13) Tender & $-0.033 * * *$ & -0.002 & $0.123^{* * *}$ & $0.484 * * *$ & $-0.200 * * *$ & $0.073 * * *$ & $0.107 * * *$ & -0.010 & -0.016 & 0.016 & $-0.026 * *$ & $0.246 * * *$ & & & \\
\hline (14) CARs ${ }_{-252,-20}$ & $-0.052 * * *$ & $0.049 * * *$ & $0.160 * * *$ & $-0.030 * *$ & $0.028 * *$ & $-0.069 * * *$ & $0.031^{* *}$ & $-0.071 * * *$ & $-0.161^{* * *}$ & $-0.039 * * *$ & -0.011 & 0.002 & 0.018 & & \\
\hline (16) CashFlow & $-0.059 * * *$ & 0.010 & $0.076 * * *$ & 0.016 & -0.012 & $-0.025 * *$ & 0.017 & $-0.030 * *$ & 0.001 & 0.003 & -0.018 & 0.004 & 0.010 & -0.004 & $-0.575^{* * *}$ \\
\hline
\end{tabular}


Table 3. GNH and CARs - Univariate results

This table shows the univariate results regarding the relation of sentiment $(G N H)$ with cumulative returns of bidders estimated over the four-day period from the merger announcement date to three days after $(0,+3)$. We first rank mergers on sentiment level and then generate quartile portfolios. High (low) sentiment is the top (bottom) quartile. $\mathrm{N}$ indicates the number of mergers available. P-values are shown in parentheses. Results shown are for the full sample of seventeen countries. ${ }^{* *}$ and ${ }^{* * *}$ indicate significance at the 5 and 1 percent levels, respectively.

\begin{tabular}{|c|c|}
\hline & $\operatorname{CARs}(0,+3)$ \\
\hline High GNH $(0,+3)$ & $\begin{array}{c}2.06^{* * *} \\
(0.000)\end{array}$ \\
\hline $\mathrm{N}$ & 1882 \\
\hline $2 \mathrm{GNH}(0,+3)$ & $\begin{array}{c}1.78^{* * *} \\
(0.000)\end{array}$ \\
\hline $\mathrm{N}$ & 1880 \\
\hline $3 \mathrm{GNH}(0,+3)$ & $\begin{array}{c}2.01 * * * \\
(0.000)\end{array}$ \\
\hline $\mathrm{N}$ & 1879 \\
\hline Low GNH $(0,+3)$ & $\begin{array}{c}0.92 * * * \\
(0.000)\end{array}$ \\
\hline $\mathrm{N}$ & 1882 \\
\hline High-Low & $\begin{array}{c}1.15^{* * *} \\
(0.001)\end{array}$ \\
\hline
\end{tabular}


Table 4. GNH and CARs - Multivariate results

Column (1) of this table explores whether the relation between sentiment and bidder returns holds after adjusting for a number of control variables, and column (2) shows the extent to which the relation is present prior to the merger announcement period. The dependent variable in column (1) is the percentage cumulative abnormal returns estimated from the merger announcement day to three days after $(0,+3)$, while in column (2) it is from -12 days to -10 prior to the merger announcement. The main independent variable under consideration is sentiment $(G N H)$, which is estimated in the interval period between 0 and +3 days after merger announcements in column (1), and -12 and -10 days prior to merger announcements in column (2). Column (3) shows the Chow test result on the statistically significant difference between columns (1) and (2). Explanatory variables are as defined in Table 2. Standard errors are clustered by country. Country dummies, and eight lags on sentiment and on stock market returns, are included. P-values are shown in parentheses. $\mathrm{N}$ indicates the number of observations. Results shown are for the full sample of seventeen countries. ${ }^{*}, * *$, and ${ }^{* * *}$ indicate significance at the 10,5 , and 1 percent levels, respectively.

\begin{tabular}{|c|c|c|c|}
\hline & $\begin{array}{c}(1) \\
\text { CARs }(0,+3) \\
\end{array}$ & $\begin{array}{c}(2) \\
\text { CARs }(-12,-10) \\
\end{array}$ & $\begin{array}{l}\text { (3) } \\
\text { Diff }\end{array}$ \\
\hline $\operatorname{GNH}(0,+3)$ & $\begin{array}{c}0.120^{* * *} \\
(0.003)\end{array}$ & & \\
\hline GNH(-12,-10) & & $\begin{array}{c}0.027 \\
(0.200)\end{array}$ & \\
\hline Difference GNH & & & $\begin{array}{c}0.093^{* * *} \\
(0.008)\end{array}$ \\
\hline LnMV & $\begin{array}{c}-0.015 * * * \\
(0.000)\end{array}$ & $\begin{array}{c}0.001 \\
(0.793)\end{array}$ & \\
\hline Public & $\begin{array}{c}-0.034 * * * \\
(0.000)\end{array}$ & $\begin{array}{l}0.004^{*} \\
(0.068)\end{array}$ & \\
\hline Private & $\begin{array}{c}-0.010 * * * \\
(0.000)\end{array}$ & $\begin{array}{c}0.001 \\
(0.650)\end{array}$ & \\
\hline Stock & $\begin{array}{l}0.008^{*} \\
(0.083)\end{array}$ & $\begin{array}{c}0.010 * * \\
(0.024)\end{array}$ & \\
\hline Cash & $\begin{array}{c}0.002 \\
(0.375)\end{array}$ & $\begin{array}{c}0.000 \\
(0.887)\end{array}$ & \\
\hline RelSize & $\begin{array}{l}0.002 * \\
(0.092)\end{array}$ & $\begin{array}{c}-0.002 \\
(0.212)\end{array}$ & \\
\hline BTMV & $\begin{array}{c}0.001 \\
(0.526)\end{array}$ & $\begin{array}{c}0.001^{* *} \\
(0.041)\end{array}$ & \\
\hline Domestic & $\begin{array}{l}-0.009 \\
(0.124)\end{array}$ & $\begin{array}{c}0.001 \\
(0.799)\end{array}$ & \\
\hline Diversified & $\begin{array}{l}-0.001 \\
(0.559)\end{array}$ & $\begin{array}{c}-0.003^{* *} \\
(0.047)\end{array}$ & \\
\hline Competitive & $\begin{array}{l}0.025^{*} \\
(0.074)\end{array}$ & $\begin{array}{l}-0.003 \\
(0.359)\end{array}$ & \\
\hline Tender & $\begin{array}{c}0.013^{* *} \\
(0.022)\end{array}$ & $\begin{array}{l}-0.002 \\
(0.542)\end{array}$ & \\
\hline CARs $_{-252,-20}$ & $\begin{array}{c}-0.005^{* *} \\
(0.040)\end{array}$ & $\begin{array}{l}-0.001 \\
(0.874)\end{array}$ & \\
\hline DebtTA & $\begin{array}{c}0.002 * * * \\
(0.000)\end{array}$ & $\begin{array}{c}-0.004 * * * \\
(0.000)\end{array}$ & \\
\hline CashFlow & $\begin{array}{c}0.001 * * * \\
(0.000)\end{array}$ & $\begin{array}{c}-0.001 * * * \\
(0.001)\end{array}$ & \\
\hline Constant & $\begin{array}{c}0.079 * * * \\
(0.000)\end{array}$ & $\begin{array}{c}-0.013 * * * \\
(0.006)\end{array}$ & \\
\hline Country Dummies & Yes & Yes & \\
\hline Lagged Sentiment & Yes & Yes & \\
\hline Lagged Market Returns & Yes & Yes & \\
\hline $\mathrm{N}$ & 6493 & 6378 & \\
\hline adj. R-sq & 0.070 & 0.029 & \\
\hline
\end{tabular}


Table 5. The relation of sentiment with lead bidder announcement returns

This table explores within a multivariate analysis the relation of sentiment with bidder cumulative abnormal returns after merger announcements $(0,+3)$ as well as from day +4 to day +12 after merger announcements. The dependent variable is the percentage cumulative returns (CARs). We also incorporate the control variables, in line with the prior multivariate table (Table 4), but due to space considerations only the parameter coefficient of sentiment $(G N H)$ is reported. Country dummies, and eight lags on sentiment and on stock market returns, are included. P-values are shown in parentheses. Results shown are for the full sample of seventeen countries. * and *** indicate significance at the 10 and 1 percent levels, respectively.

\begin{tabular}{cc} 
Days & CARs $(0,+3)$ \\
\hline$(0,+3)$ & $0.120 * * *$ \\
& $(0.003)$ \\
+4 & $-0.072^{* * *}$ \\
& $(0.000)$ \\
+5 & -0.000 \\
& $(0.990)$ \\
+6 & -0.002 \\
& $(0.917)$ \\
+7 & 0.035 \\
& $(0.267)$ \\
+8 & -0.012 \\
& $(0.520)$ \\
+9 & 0.009 \\
& $(0.560)$ \\
+10 & 0.027 \\
& $(0.215)$ \\
+11 & 0.018 \\
& $(0.193)$ \\
+12 & $-0.032 *$ \\
& $(0.062)$ \\
\hline
\end{tabular}


Table 6. Sub-Group Analysis: Univariate results

This table shows the univariate results regarding the relation of sentiment (GNH) with cumulative abnormal returns of bidders for a number of subgroups. In Panel A we explore the percentage of blockholder ownership in a firm, the target status, and the relative size between bidder and target firms, while in Panel B we report results for the method of payment and the market capitalization (size) of bidders. Blockholder ownership indicates the percentage of shares held by strategic shareholders owning 5 percent or more. Targets may be private or public firms. We first identify the top and bottom quartile per country for each characteristic and then rank them based on the level of sentiment. GNH and returns are estimated over the four-day period from the merger announcement to three days after $(0,+3)$. $\mathrm{N}$ indicates the number of mergers available. P-values are shown in parentheses. Results shown are for the full sample of seventeen countries. ${ }^{*}, * *$, and ${ }^{* * *}$ indicate significance at the 10,5 , and 1 percent levels, respectively.

\begin{tabular}{|c|c|c|c|c|c|c|c|c|}
\hline \multicolumn{9}{|c|}{ Panel A: Blockholder Ownership, Target Status, and Relative Size } \\
\hline & \multicolumn{2}{|c|}{ Blockholder } & \multicolumn{2}{|c|}{ Target Status } & \multicolumn{2}{|c|}{ Low Blockholder } & \multicolumn{2}{|c|}{ RelSize } \\
\hline & Low & High & Public & Private & Public & Private & High & Low \\
\hline \multirow[t]{2}{*}{ High GNH(0,+3) } & $1.22 * * *$ & $1.59^{* * *}$ & -0.17 & $2.23 * * *$ & -0.59 & $0.95^{* *}$ & $4.80^{* * *}$ & $0.66^{* * *}$ \\
\hline & $(0.000)$ & $(0.000)$ & $(0.775)$ & $(0.000)$ & $(0.302)$ & $(0.045)$ & $(0.000)$ & $(0.003)$ \\
\hline $\mathrm{N}$ & 568 & 1092 & 264 & 963 & 106 & 256 & 469 & 469 \\
\hline \multirow[t]{2}{*}{ Low GNH $(0,+3)$} & -0.23 & $1.21^{* * *}$ & $-2.98 * * *$ & $1.48^{* * *}$ & $-3.82 * * *$ & -0.32 & $1.71^{* *}$ & 0.10 \\
\hline & $(0.590)$ & $(0.000)$ & $(0.000)$ & $(0.000)$ & $(0.000)$ & $(0.642)$ & $(0.025)$ & $(0.730)$ \\
\hline $\mathrm{N}$ & 567 & 1093 & 264 & 962 & 106 & 256 & 469 & 468 \\
\hline High-Low & $1.45^{* * *}$ & 0.39 & $2.81^{* * *}$ & 0.75 & $3.23^{* * *}$ & 1.27 & $3.08^{* * *}$ & 0.56 \\
\hline & $(0.007)$ & $(0.334)$ & $(0.002)$ & $(0.127)$ & $(0.006)$ & $(0.130)$ & $(0.002)$ & $(0.136)$ \\
\hline
\end{tabular}

Panel B: Method of Payment and Bidder Size Expectation

\begin{tabular}{lccccc} 
& \multicolumn{3}{c}{ Method of Payment } & \multicolumn{2}{c}{ Size } \\
& Cash & Stock & Mixed & Large & Small \\
\hline High GNH(0,+3) & $1.34^{* * *}$ & $4.73^{* * *}$ & $1.93^{* * *}$ & $0.84^{* * *}$ & $5.07^{* * *}$ \\
& $(0.000)$ & $(0.000)$ & $(0.000)$ & $(0.000)$ & $(0.000)$ \\
$\mathrm{N}$ & 564 & 209 & 1108 & 469 & 469 \\
& & & & & \\
Low GNH(0,+3) & 0.45 & 2.07 & $1.05^{* * *}$ & -0.50 & $2.63^{* * *}$ \\
& $(0.163)$ & $(0.107)$ & $(0.001)$ & $(0.108)$ & $(0.001)$ \\
High-Low & 564 & 209 & 1107 & 469 & 468 \\
& & & & & \\
& $0.88^{* *}$ & 2.66 & $0.88^{* *}$ & $1.34^{* * *}$ & $2.44^{* *}$ \\
& $(0.041)$ & $(0.119)$ & $(0.030)$ & $(0.001)$ & $(0.019)$ \\
\hline
\end{tabular}


Table 7. Sub-Group Analysis: Multivariate results

This table explores within a multivariate analysis the relation of sentiment with bidder cumulative abnormal returns within alternative subgroups: low levels of strategic blockholder ownership, public targets, and high relative size of target to bidder mergers. The dependent variable is the percentage cumulative returns (CARs) estimated over the four-day period from the merger announcement to three days after $(0,+3)$. Other explanatory variables are as defined in Table 2. Standard errors are clustered by country. Country dummies, and eight lags on sentiment and on stock market returns, are included. P-values are shown in parentheses. $\mathrm{N}$ indicates the number of observations. Results shown are for the full sample of seventeen countries. ${ }^{*}, * *$, and $* * *$ indicate significance at the 10,5 , and 1 percent levels, respectively.

\begin{tabular}{|c|c|c|c|c|}
\hline & $\begin{array}{c}(1) \\
\text { CARs }(0,+3)\end{array}$ & $\begin{array}{c}(2) \\
\operatorname{CARs}(0,+3)\end{array}$ & $\begin{array}{c}(3) \\
\text { CARs }(0,+3)\end{array}$ & $\begin{array}{c}(4) \\
\text { CARs }(0,+3)\end{array}$ \\
\hline $\operatorname{GNH}(0,+3)$ & $\begin{array}{l}-0.028 \\
(0.576)\end{array}$ & $\begin{array}{c}0.081^{* *} \\
(0.012)\end{array}$ & $\begin{array}{c}0.011 \\
(0.846)\end{array}$ & $\begin{array}{c}0.021 \\
(0.663)\end{array}$ \\
\hline LowBlock & $\begin{array}{c}0.002 \\
(0.172)\end{array}$ & & $\begin{array}{l}-0.001 \\
(0.876)\end{array}$ & \\
\hline LowBlock*GNH $(0,+3)$ & $\begin{array}{c}0.281^{* * *} \\
(0.003)\end{array}$ & & & \\
\hline Public*GNH $(0,+3)$ & & $\begin{array}{l}0.276^{* * *} \\
(0.002)\end{array}$ & & \\
\hline LowBlock*Public & & & $\begin{array}{c}0.007 \\
(0.422)\end{array}$ & \\
\hline LowBlock*Private & & & $\begin{array}{l}-0.002 \\
(0.851)\end{array}$ & \\
\hline LowBlock*Public*GNH $(0,+3)$ & & & $\begin{array}{l}0.477^{*} \\
(0.065)\end{array}$ & \\
\hline LowBlock*Private*GNH $(0,+3)$ & & & $\begin{array}{c}0.130 \\
(0.521)\end{array}$ & \\
\hline RelSizeHigh & & & & $\begin{array}{c}0.021^{* * *} \\
(0.000)\end{array}$ \\
\hline RelSizeHigh*GNH $(0,+3)$ & & & & $\begin{array}{c}0.462 * * * \\
(0.004)\end{array}$ \\
\hline LnMV & $\begin{array}{l}-0.012 * * * \\
(0.000)\end{array}$ & $\begin{array}{l}-0.015^{* * *} \\
(0.000)\end{array}$ & $\begin{array}{l}-0.012 * * * \\
(0.000)\end{array}$ & $\begin{array}{l}-0.012^{* * *} \\
(0.000)\end{array}$ \\
\hline Public & $\begin{array}{l}-0.033^{* * *} \\
(0.000)\end{array}$ & $\begin{array}{c}-0.030^{* * *} \\
(0.000)\end{array}$ & $\begin{array}{c}-0.034 * * * \\
(0.000)\end{array}$ & $\begin{array}{l}-0.036 * * * \\
(0.000)\end{array}$ \\
\hline Private & $\begin{array}{l}-0.010 * * * \\
(0.000)\end{array}$ & $\begin{array}{l}-0.010^{* * *} \\
(0.000)\end{array}$ & $\begin{array}{c}-0.009 * * \\
(0.032)\end{array}$ & $\begin{array}{l}-0.008^{* * *} \\
(0.000)\end{array}$ \\
\hline Stock & $\begin{array}{c}0.005 \\
(0.491)\end{array}$ & $\begin{array}{l}0.008^{*} \\
(0.085)\end{array}$ & $\begin{array}{c}0.005 \\
(0.487)\end{array}$ & $\begin{array}{c}0.007 \\
(0.116)\end{array}$ \\
\hline Cash & $\begin{array}{c}0.003 \\
(0.182)\end{array}$ & $\begin{array}{c}0.002 \\
(0.386)\end{array}$ & $\begin{array}{c}0.003 \\
(0.183)\end{array}$ & $\begin{array}{c}0.003 \\
(0.245)\end{array}$ \\
\hline RelSize & $\begin{array}{l}0.006^{* *} \\
(0.013)\end{array}$ & $\begin{array}{l}0.002^{*} \\
(0.092)\end{array}$ & $\begin{array}{l}0.006^{* *} \\
(0.013)\end{array}$ & $\begin{array}{c}0.001 \\
(0.201)\end{array}$ \\
\hline BTMV & $\begin{array}{c}0.001 \\
(0.782)\end{array}$ & $\begin{array}{c}0.001 \\
(0.525)\end{array}$ & $\begin{array}{c}0.001 \\
(0.775)\end{array}$ & $\begin{array}{c}0.001 \\
(0.567)\end{array}$ \\
\hline Domestic & $\begin{array}{l}-0.006 \\
(0.176)\end{array}$ & $\begin{array}{l}-0.009 \\
(0.127)\end{array}$ & $\begin{array}{l}-0.006 \\
(0.162)\end{array}$ & $\begin{array}{l}-0.009 \\
(0.113)\end{array}$ \\
\hline Diversified & $\begin{array}{l}-0.002 \\
(0.552)\end{array}$ & $\begin{array}{l}-0.001 \\
(0.542)\end{array}$ & $\begin{array}{l}-0.002 \\
(0.545)\end{array}$ & $\begin{array}{l}-0.001 \\
(0.768)\end{array}$ \\
\hline Competitive & $\begin{array}{l}0.018^{*} \\
(0.058)\end{array}$ & $\begin{array}{l}0.024^{*} \\
(0.088)\end{array}$ & $\begin{array}{l}0.017 * \\
(0.065)\end{array}$ & $\begin{array}{l}0.025^{*} \\
(0.071)\end{array}$ \\
\hline Tender & $\begin{array}{c}0.014^{* * *} \\
(0.001)\end{array}$ & $\begin{array}{l}0.013^{* *} \\
(0.025)\end{array}$ & $\begin{array}{c}0.014^{* * *} \\
(0.001)\end{array}$ & $\begin{array}{c}0.014^{* *} \\
(0.010)\end{array}$ \\
\hline CARs $_{-252,-20}$ & $\begin{array}{l}-0.002 \\
(0.314)\end{array}$ & $\begin{array}{c}-0.005^{* *} \\
(0.041)\end{array}$ & $\begin{array}{l}-0.002 \\
(0.322)\end{array}$ & $\begin{array}{c}-0.004 * * \\
(0.048)\end{array}$ \\
\hline DebtTA & $\begin{array}{c}-0.004^{* * *} \\
(0.000)\end{array}$ & $\begin{array}{c}0.002 * * * \\
(0.000)\end{array}$ & $\begin{array}{c}-0.004^{* * *} \\
(0.000)\end{array}$ & $\begin{array}{c}0.002 * * * \\
(0.000)\end{array}$ \\
\hline CashFlow & $-0.003 * * *$ & $0.001 * * *$ & $-0.003 * * *$ & $0.001 * * *$ \\
\hline
\end{tabular}




\section{Constant}

Country Dummies

Lagged Sentiment

Lagged Market Returns

$\mathrm{N}$

adj. R-sq

\begin{tabular}{cccc}
$(0.000)$ & $(0.000)$ & $(0.000)$ & $(0.000)$ \\
$0.066^{* * *}$ & $0.078^{* * *}$ & $0.066^{* * *}$ & $0.064^{* * *}$ \\
$(0.000)$ & $(0.000)$ & $(0.000)$ & $(0.000)$ \\
Yes & Yes & Yes & Yes \\
Yes & Yes & Yes & Yes \\
Yes & Yes & Yes & Yes \\
5928 & 6493 & 5928 & 6493 \\
0.068 & 0.070 & 0.067 & 0.074 \\
\hline
\end{tabular}


Table 8. GNH and CAR: US results

This table explores within a multivariate framework whether the relation of sentiment with bidder returns holds within the sample of US mergers. The regression is estimated for the whole US sample as well as for subgroups based on strategic blockholder ownership, target status, the interaction between low ownership and the target status, and the relative size between targets and bidders. The dependent variable is the percentage cumulative abnormal returns (CARs) estimated over the four-day period from the merger announcement day to three days after $(0,+3)$. Explanatory variables are the same as in Table 7 . P-values are shown in parentheses. $\mathrm{N}$ indicates the number of observations. $*, * *$, and $* * *$ indicate significance at the 10,5 , and 1 percent levels, respectively.

\begin{tabular}{|c|c|c|c|c|c|}
\hline & $\begin{array}{c}(1) \\
\text { CARs }(0,+3\end{array}$ & $\begin{array}{c}(2) \\
\operatorname{CARs}(0,+3)\end{array}$ & $\begin{array}{c}(3) \\
\text { CARs }(0,+3)\end{array}$ & $\begin{array}{c}(4) \\
\text { CARs }(0,+3)\end{array}$ & $\begin{array}{c}(5) \\
\text { CARs }(0,+3)\end{array}$ \\
\hline US-GNH $(0,+3)$ & $\begin{array}{c}0.115 \\
(0.198)\end{array}$ & $\begin{array}{c}-0.003 \\
(0.973)\end{array}$ & $\begin{array}{c}0.052 \\
(0.584)\end{array}$ & $\begin{array}{c}0.045 \\
(0.641)\end{array}$ & $\begin{array}{c}-0.013 \\
(0.897)\end{array}$ \\
\hline LowBlock & & $\begin{array}{c}0.004 \\
(0.306)\end{array}$ & & $\begin{array}{c}-0.008 \\
(0.122)\end{array}$ & \\
\hline LowBlock*US-GNH(0,+3) & & $\begin{array}{c}0.490 * * * \\
(0.003)\end{array}$ & & & \\
\hline Public*US-GNH $(0,+3)$ & & & $\begin{array}{c}0.415^{* *} \\
(0.044)\end{array}$ & & \\
\hline LowBlock*Public & & & & $\begin{array}{c}0.024^{* *} \\
(0.018)\end{array}$ & \\
\hline LowBlock*Private & & & & $\begin{array}{c}0.011 \\
(0.133)\end{array}$ & \\
\hline LowBlock*Public*US-GNH(0,+3) & & & & $\begin{array}{l}0.736^{* *} \\
(0.015)\end{array}$ & \\
\hline LowBlock*Private*US-GNH $(0,+3)$ & & & & $\begin{array}{l}0.401^{*} \\
(0.094)\end{array}$ & \\
\hline RelSizeHigh & & & & & $\begin{array}{l}0.020 * * * \\
(0.000)\end{array}$ \\
\hline RelSizeHigh*US-GNH $(0,+3)$ & & & & & $\begin{array}{c}0.570 * * * \\
(0.001)\end{array}$ \\
\hline Firm Characteristics & Yes & Yes & Yes & Yes & Yes \\
\hline Merger Characteristics & Yes & Yes & Yes & Yes & Yes \\
\hline Lagged Sentiment & Yes & Yes & Yes & Yes & Yes \\
\hline Lagged Market Returns & Yes & Yes & Yes & Yes & Yes \\
\hline $\mathrm{N}$ & 3063 & 3031 & 3063 & 3031 & 3063 \\
\hline adj. R-sq & 0.114 & 0.122 & 0.115 & 0.121 & 0.118 \\
\hline
\end{tabular}


Table 9. US results with the use of the Gallup Economic Confidence Index

This table explores within a multivariate framework the relation of sentiment, as proxied by the Gallup US Economic Confidence Index, with bidder returns within the sample of US mergers. The dependent variable is the percentage cumulative abnormal returns (CARs) estimated over the four-day period from the merger announcement to three days after $(0,+3)$. Explanatory variables are the same as in Table 7. P-values are shown in parentheses. $\mathrm{N}$ indicates the number of observations. Gallup's data commence on January 2008. *, **, and *** indicate significance at the 10,5 , and 1 percent levels, respectively.

\begin{tabular}{|c|c|c|c|c|c|}
\hline & $\begin{array}{c}(1) \\
\text { CARs(0, }\end{array}$ & $\begin{array}{c}(2) \\
\text { CARs }(0,+3)\end{array}$ & $\begin{array}{c}(3) \\
\text { CARs }(0,+3) \\
\end{array}$ & $\begin{array}{c}(4) \\
\text { CARs }(0,+3)\end{array}$ & $\begin{array}{c}(5) \\
\operatorname{CARs}(0,+3) \\
\end{array}$ \\
\hline US-Gallup $(0,+3)$ & $\begin{array}{c}0.055^{* *} \\
(0.001)\end{array}$ & $\begin{array}{l}0.035^{*} \\
(0.082)\end{array}$ & $\begin{array}{l}0.030^{*} \\
(0.087)\end{array}$ & $\begin{array}{c}0.043^{* *} \\
(0.018)\end{array}$ & $\begin{array}{c}0.036^{* *} \\
(0.045)\end{array}$ \\
\hline LowBlock & & $\begin{array}{l}0.017^{*} \\
(0.099)\end{array}$ & & $\begin{array}{l}-0.007 \\
(0.214)\end{array}$ & \\
\hline LowBlock*US-Gallup $(0,+3)$ & & $\begin{array}{c}0.056^{* *} \\
(0.039)\end{array}$ & & & \\
\hline Public*US-Gallup $(0,+3)$ & & & $\begin{array}{c}0.168 * * * \\
(0.000)\end{array}$ & & \\
\hline LowBlock*Public & & & & $\begin{array}{c}0.063 * * * \\
(0.003)\end{array}$ & \\
\hline LowBlock*Private & & & & $\begin{array}{c}0.011 \\
(0.426)\end{array}$ & \\
\hline LowBlock*Public*US-Gallup $(0,+3)$ & & & & $\begin{array}{c}0.147 * * * \\
(0.008)\end{array}$ & \\
\hline LowBlock*Private*US-Gallup $(0,+3)$ & & & & $\begin{array}{c}0.023 \\
(0.507)\end{array}$ & \\
\hline RelSizeHigh & & & & & $\begin{array}{c}0.043^{* * *} \\
(0.000)\end{array}$ \\
\hline RelSizeHigh*US-Gallup $(0,+3)$ & & & & & $\begin{array}{c}0.082 * * * \\
(0.010)\end{array}$ \\
\hline Firm Characteristics & Yes & Yes & Yes & Yes & Yes \\
\hline Merger Characteristics & Yes & Yes & Yes & Yes & Yes \\
\hline Lagged Sentiment & Yes & Yes & Yes & Yes & Yes \\
\hline Lagged Market Returns & Yes & Yes & Yes & Yes & Yes \\
\hline $\mathrm{N}$ & 2786 & 2763 & 2786 & 2763 & 2786 \\
\hline adj. R-sq & 0.127 & 0.130 & 0.132 & 0.131 & 0.131 \\
\hline
\end{tabular}


Table 10 GNH and CAR: Non-US results

This table explores within a multivariate framework whether the relation of sentiment with bidder returns holds within the remaining countries when excluding US mergers (NonUS). The regression is estimated for the NonUS sample as well as for subgroups based on strategic blockholder ownership, target status, the interaction between low ownership and the target status, and the relative size between targets and bidders. The dependent variable is the percentage cumulative abnormal returns (CARs) estimated over the four-day period from the merger announcement to three days after $(0,+3)$. Explanatory variables are the same as in Table 7 . P-values are shown in parentheses. $\mathrm{N}$ indicates the number of observations. Results shown are for the sample of sixteen countries. *, **, and *** indicate significance at the 10,5 , and 1 percent levels, respectively.

\begin{tabular}{|c|c|c|c|c|c|}
\hline & $\begin{array}{c}(1) \\
\text { CARs }(0,+3)\end{array}$ & $\begin{array}{c}(2) \\
\text { CARs }(0,+3)\end{array}$ & $\begin{array}{c}(3) \\
\text { CARs }(0,+3)\end{array}$ & $\begin{array}{c}(4) \\
\text { CARs }(0,+3)\end{array}$ & $\begin{array}{c}(5) \\
\text { CARs }(0,+3)\end{array}$ \\
\hline NonUS-GNH $(0,+3)$ & $\begin{array}{l}0.110^{* *} \\
(0.046)\end{array}$ & $\begin{array}{l}-0.107 \\
(0.212)\end{array}$ & $\begin{array}{l}0.085^{*} \\
(0.062)\end{array}$ & $\begin{array}{l}-0.053 \\
(0.569)\end{array}$ & $\begin{array}{c}0.037 \\
(0.576)\end{array}$ \\
\hline LowBlock & & $\begin{array}{c}0.001 \\
(0.564)\end{array}$ & & $\begin{array}{c}0.006 \\
(0.220)\end{array}$ & \\
\hline LowBlock*NonUS-GNH(0,+3) & & $\begin{array}{l}0.211^{*} \\
(0.072)\end{array}$ & & & \\
\hline Public*NonUS-GNH $(0,+3)$ & & & $\begin{array}{c}0.193 \\
(0.243)\end{array}$ & & \\
\hline LowBlock*Public & & & & $\begin{array}{c}-0.005 \\
(0.549)\end{array}$ & \\
\hline LowBlock*Private & & & & $\begin{array}{l}-0.013 \\
(0.175)\end{array}$ & \\
\hline LowBlock*Public*NonUS-GNH(0,+3) & & & & $\begin{array}{c}0.418 \\
(0.361)\end{array}$ & \\
\hline LowBlock*Private*NonUS-GNH $(0,+3)$ & & & & $\begin{array}{l}-0.029 \\
(0.855)\end{array}$ & \\
\hline RelSizeHigh & & & & & $\begin{array}{c}0.015^{* * *} \\
(0.005)\end{array}$ \\
\hline RelSizeHigh*NonUS-GNH $(0,+3)$ & & & & & $\begin{array}{l}0.335^{*} \\
(0.055)\end{array}$ \\
\hline Firm Characteristics & Yes & Yes & Yes & Yes & Yes \\
\hline Merger Characteristics & Yes & Yes & Yes & Yes & Yes \\
\hline Country Dummies & Yes & Yes & Yes & Yes & Yes \\
\hline Lagged Sentiment & Yes & Yes & Yes & Yes & Yes \\
\hline Lagged Market Returns & Yes & Yes & Yes & Yes & Yes \\
\hline $\mathrm{N}$ & 3430 & 2897 & 3430 & 2897 & 3430 \\
\hline adj. R-sq & 0.061 & 0.050 & 0.061 & 0.050 & 0.063 \\
\hline
\end{tabular}

